\title{
MUSCLE OXYGENATION OF THE QUADRICEPS AND GASTROCNEMIUS DURING MAXIMAL AEROBIC EFFORT
}

\author{
OXIGENAÇÃO MUSCULAR DE QUADRÍCEPS E GASTROCNÊMIO DURANTE O ESFORÇO AERÓBICOMÁXIMO \\ OXIGENACIÓN MUSCULARDE CUÁDRICEPS Y GASTROCNEMIO DURANTEEL ESFUERZO AERÓBICOMÁXIMO
}

Original Article

ARTIGO ORIGINAL

Artículo Original

María-José Paredes-Ruiz' (DD (Physician and Physiotherapist) María Jódar-Reverte ${ }^{1}$ (iD) (Nurse)

Vicente Ferrer-López' (iD (Physician)

Ignacio Martínez González-Moro' (ID (Physician)

1. Universidad de Murcia,

University Institute for Research on Aging. Research Group on Physical Exercise and Human Performance, Murcia, Spain.

\section{Correspondence:}

Ignacio Martínez González-Moro. University of Murcia. Edif. LAIB. Campus Health Sciences. Avda. Buenavista, s/n, El Palmar, Murcia, Spain. 30120

ignaciomgm@um.es

\begin{abstract}
Introduction: Near infrared spectroscopy (NIRS) is a non-invasive technique that is used in the assessment of tissue oxygenation and the monitoring of physical activity. Objective: To determine the influence of sexual, anthropometric and ergospirometric factors on muscle oxygenation of the quadriceps and gastrocnemius, obtained by NIRS during a stress test. Methods: Twenty healthy subjects participated in this study (10 women). Two Humon Hex ${ }^{\oplus}$ devices were placed on the dominant side of the quadriceps and gastrocnemius muscles to measure muscle oxygen saturation ( $\mathrm{SmO} 2$ ). The stress test was performed on a treadmill with electrocardiographic control and measurement of oxygen consumption. $\mathrm{SmO} 2$ was obtained at rest and after maximum effort during the stress test. In addition, the height, weight, skinfold and waist contour were measured. Bioimpedance was used to obtain the percentages of fat mass and muscle mass, which were used to calculate the relative fat mass (RFM). Results: The SmO2 of both muscles at rest is higher in males than in females. At maximum effort, the $\mathrm{SmO} 2$ of the quadriceps is similar in both groups. The $\mathrm{SmO} 2$ of both muscles is positively related to height, body mass, percentage of mass muscle and waist contour, and negatively with percentage of mass fat, RFM and skinfold thickness. The negative correlation between fat percentage and oxygen saturation is more evident in females. It was observed that the variables that quantify maximum effort are not related to the $\mathrm{SmO} 2$ values, except for the correlation between $\mathrm{HR}$ max and $\mathrm{SmO} 2$ of the gastrocnemius muscle in males. Conclusion: The $\mathrm{SmO} 2$ of recreational athletes is influenced by the location of the device and the fat mass of the subjects. The biggest differences between the sexes are in the gastrocnemius muscle. Level of Evidence Il; Diagnostic Studies - Investigating a Diagnostic Test.
\end{abstract}

Keywords: Spectroscopy, near-infrared; Exercise tolerance; Oxygen consumption; Muscle, skeletal; Quadriceps muscle.

\section{RESUMO}

Introdução: A espectroscopia de infravermelho próximo (NIRS) é uma técnica não invasiva usada na avaliação da oxigenação tecidual e no monitoramento da atividade física. Objetivos: Determinar a influência de fatores sexuais, antropométricos e ergoespirométricos sobre a oxigenação muscular do quadríceps e do gastrocnêmio obtidos por NIRS durante um teste de esforço. Métodos: Participaram deste estudo 20 indivíduos saudáveis (10 mulheres). Dois dispositivos Humon Hex ${ }^{\varpi}$ foram colocados no lado dominante dos músculos quadriceps e gastrocnêmio para medir a saturação de oxigênio muscular $\left(\mathrm{SmO}_{2}\right)$. O teste de esforço foi realizado em uma esteira com controle eletrocardiográfico e mensuração do consumo de oxigênio. A SmO $\mathrm{S}_{2}$ foi obtida em repouso e depois de esforço máximo durante o teste. Além disso, foram medidos estatura, peso, dobras cutâneas e contorno da cintura. A bioimpedância foi usada para obter os percentuais de massa gorda e massa muscular, que foram usados para calcular a massa gorda relativa (MGR). Resultados: $\mathrm{ASmO}_{2}$ de ambos os músculos em repouso é maior em homens do que em mulheres. No esforço máximo, a $\mathrm{SmO}_{2}$ do quadríceps é semelhante nos dois os grupos. A $\mathrm{SmO}_{2}$ de ambos os músculos é positivamente relacionada com estatura, massa corporal, percentual de massa muscular e contorno da cintura e negativamente relacionada com a porcentagem de massa gorda, MGR e espessura das dobras cutâneas. A correlação negativa entre o percentual de gordura e a saturação de oxigênio é mais evidente nas mulheres. Observou-se que variáveis que quantificam o esforço máximo não estão relacionadas com os valores $\mathrm{SmO2}$, exceto pela correlação entre FCmáx e $\mathrm{SmO}_{2}$ do músculo gastrocnêmio no sexo masculino. Conclusão: $\mathrm{A} \mathrm{SmO}_{2}$ dos atletas recreativos é influenciada pela localização do dispositivo e pela massa gorda dos indivíduos. As maiores diferenças entre os sexos estão no músculo gastrocnêmio. Nível de Evidência Il; Estudos diagnósticos - Investigação de um exame para diagnóstico.

Descritores: Espectroscopia de luz próxima ao infravermelho; Tolerância ao exercício; Consumo de oxigênio; Músculo esquelético; Músculo quadríceps.

\section{RESUMEN}

Introducción: La espectroscopia de infrarrojo cercano (NIRS) es una técnica no invasiva usada en la evaluación de la oxigenación tisular y en la monitorización de la actividad física. Objetivos: Determinar la influencia de factores sexuales, antropométricos y ergoespirométricos sobre la oxigenación muscular de cuádriceps y del gastrocnemio, obtenidos por NIRS durante un test de esfuerzo. Métodos: Participaron en este estudio 20 individuos saludables (10 
mujeres). Se colocaron dos dispositivos Humon Hex en el lado dominante de los músculos cuádriceps y gastrocnemio para medir la saturación de oxígeno muscular $\left(\mathrm{SmO}_{2}\right)$. El test de esfuerzo fue realizado en una cinta ergométrica con control electrocardiográfico y medición del consumo de oxígeno. La SmO $\mathrm{S}_{2}$ fue obtenida en reposo y después de esfuerzo máximo durante el test. Además, fueron medidos altura, peso, pliegues cutáneos y contorno de la cintura. Fue usada bioimpedancia para obtener los porcentuales de masa grasa y masa muscular, que fueron usados para calcular la masa grasa relativa (MGR). Resultados: $\mathrm{La} \mathrm{SmO}_{2}$ de ambos músculos en reposo es mayor en hombres que en mujeres. En el esfuerzo máximo la $\mathrm{SmO}_{2}$ del cuádriceps es semejante en los dos grupos. La SmO ${ }_{2}$ de ambos músculos es positivamente relacionada con altura, masa corporal, porcentual de masa muscular y contorno de la cintura y negativamente relacionada con el porcentaje de masa grasa, MGRy espesor de los pliegues cutáneos. La correlación negativa entre el porcentual de grasa y la saturación de oxígeno es más evidente en las mujeres. Se observó que variables que cuantifican el esfuerzo máximo no está relacionadas con los valores $\mathrm{SmO}_{2}$ excepto por la correlación entre FCmáx y SmO2 del músculo gastrocnemio en sexo masculino. Conclusión: La SmO2 de los atletas recreativos es influenciada por la localización del dispositivo y por la masa grasa de los individuos. Las mayores diferencias entre los sexos están en el músculo gastrocnemio. Nivel de Evidencia Il; Estudios diagnósticos - Investigación de un examen para diagnóstico.

Descriptores: Espectroscopía infrarroja corta; Tolerancia al ejercicio; Consumo de oxígeno; Músculo esquelético; Músculo cuádriceps.

\section{INTRODUCTION}

Near infrared spectroscopy (NIRS) is a non-invasive technique, which is used for the assessment of tissue oxygenation. The absorption of infrared light varies depending on the state of oxygenation and deoxygenation of the molecules of haemoglobin and myoglobin. ${ }^{2}$ NIRS estimates muscle oxygen saturation $\left(\% \mathrm{SmO}_{2}\right)$ from the ratio of oxyhaemoglobin to total haemoglobin in the blood, expressing it as a percentage. ${ }^{1}$

There are studies that have demonstrated the ability of NIRS to assess mitochondrial oxidative capacity in various muscles and exerciseinduced adaptations in muscle mitochondrial function, both in control subjects and carriers of pathologies. ${ }^{3}$ Oxidative phosphorylation is an oxygen-dependent biochemical process that converts biofuels to ATP and functions as the primary mechanism of energy production at rest and during aerobic exercise. ${ }^{4}$

The changes in $\mathrm{SmO}_{2}$ during exercise are related to the availability of oxygen in the blood and the use of that oxygen in the active muscles. ${ }^{5}$ Considering that the sports performance of skeletal muscle depends on oxidative metabolism, NIRS is an excellent technique to relate both issues and improvements in the body's oxidative system lead to higher performance in sports activities. ${ }^{6}$ Proving that a favourable $\mathrm{SmO}_{2}$ rate is associated with increased physical exercise capacity. ${ }^{7}$

The muscle most used to monitor $\mathrm{SmO}_{2}$ through NIRS is the vastus lateralis $(\mathrm{VL})^{8}$ and to a lesser extent the medial gastrocnemius (GM)? Usually a single device is used to study muscle oxygenation although there are studies that have analysed both muscles to see the influence of stretching on resistance. ${ }^{9}$ Both quadriceps and gastrocnemius have a direct action in walking and in running, ${ }_{1}^{10}$ so the results obtained will depend on their energy production capacity during the tests and the protocol used. ${ }^{11}$ The new NIRS devices are associated with display screens (computer, tablet or watch), which allow the measurement in real time the level of $\mathrm{SmO}_{2}$ that the body uses during physical exercise, outdoor and in laboratory tests. ${ }^{11,12}$ In this way, the athlete can quickly and easily interpret and apply the data obtained, ${ }^{13}$ modifying their effort to adjust to their aerobic capacity without exceeding their limits. ${ }^{14}$ For the correct interpretation and evaluation of the data obtained, the adipose tissue must be taken into account as it can interfere with the results. ${ }^{15}$

There are authors who have related anthropometric variables with oxygen muscle saturation, the area of the muscle section obtained by ultrasound ${ }_{1}^{16}$ white adipose tissue, ${ }^{17}$ skin folds, ${ }^{18}$ muscle thickness and tissue adipose with ultrasound. ${ }^{10,19}$ Being a recent technique, it is necessary to know more about its contributions to achieve a more reliable interpretation of its results.

Our aim was to determine the influence of sex, anthropometric and ergospirometric factors on quadriceps and gastrocnemius muscle oxygenation obtained by NIRS.

\section{METHODS}

20 young adults (50\% females) were recruited from our university. The inclusive criteria ware searched to identify subjects between 18 and 25 years old, not suffering from diseases, injuries or defects that prevent the performance of a stress test.

This observational study consisted of relating anthropometric and ergometric variables to $\mathrm{SmO}_{2}$. To do this, all participants were measured anthropometric variables and performed a treadmill stress test. During the stress test, maximum oxygen consumption was obtained and the electrocardiogram was continuously recorded.

\section{Anthropometric and body composition assessment}

Anthropometric measurements were made by a sufficiently trained researcher after calibrating all the instruments. The height was determined for each subject (SECA height rod) and the total body mass with a bioimpedance scale (InBody 120 ${ }^{\circledR}$ ). Both were measured without shoes and light clothing. Standing on the electrodes of the scale, the body mass was determined and the data corresponding to sex, age and height were entered into the software of the scale. Participants held the handlebars of the device with both hands placing their fingers and arms according to the instruction manual. Data for fat and musculoskeletal masses and their percentages were obtained.

With a tape measure (Holtain ${ }^{\circledR}$ ) the following perimeters were measured: waist, thigh (at the midpoint between the inguinal crease and the upper edge of the patella), and leg (at the point of maximum perimeter of the gastrocnemius). The anterior skin folds of the thigh and the medial fold of the leg were also determined using a $0.2 \mathrm{~mm}$ Holtain ${ }^{\circledR}$ precision calliper.

The body mass index (BMI) $\left(\mathrm{kg} / \mathrm{m}^{2}\right)$ was calculated and the relative fat mass (RFM) was determined applying the formula: ${ }^{20}$ RFM = $64-\left(20^{*}\right.$ (height/waist $\left.)\right)+\left(12^{*}\right.$ sex $)$ [sex is replaced by 0 in male and 1 in female]. 


\section{Stress test}

First, with the patient in the supine position, the cardiovascular measurements were carried out at rest by means of cardiac auscultation, blood pressure and electrocardiogram (ECG). Subsequently, the electrodes were collected to keep a record of the ECG throughout the entire stress test and a pulsometer was placed to monitor the heart rate linked to the tablet where the information from the Humon Hex ${ }^{\oplus}$ is collected.

The stress test was performed on a treadmill (model run7411) with a continuous and progressive ramp protocol. It starts at seven $\mathrm{km} / \mathrm{h}$ and increases $0.1 \mathrm{~km} / \mathrm{h}$ every six seconds. The slope remained constant at $1 \%$. The test ended when the subject could no longer run and made a gesture with his hand, then the recovery phase began at $4 \mathrm{~km} / \mathrm{h}$ for three minutes, and at rest for another two minutes. The tests were considered to be maximal and valid when they exceeded $85 \%$ of the theoretical maximum heart rate (220-age) and the respiratory quotient (RER) was greater than 1.15.21

Throughout the stress test the subjects breathed through a mask connected to a gas analyser (Metalyzer $3 b^{\star}$, Cortex). Heart rate and electrocardiographic recording were obtained with the Cardioline Cube ${ }^{\oplus}$ device. All tests were carried out under similar environmental conditions (temperature 20-22 degrees). The method used to determine the maximum oxygen consumption was to reach the oxygen consumption plateau. ${ }^{2}$

\section{Placement of the measuring devices of the $\mathrm{SmO}_{2}$}

Each participant had two Humon Hex ${ }^{\oplus}$ devices placed on their dominant side, one for the quadriceps, on the vast lateral, at the midpoint of the line between the inguinal fold and the superior pole of the patella, and another for the external gastrocnemius, on the area with the largest diameter of the leg.

Each Humon Hex ${ }^{\oplus}$ was synchronized with a Samsung ${ }^{\circledast}$ Tablet connected to the corresponding APP to visualize the information on $\mathrm{SmO}^{2}$, the exercise time, and the heart rate. ${ }^{12}$

\section{Statistical procedure}

After ruling out the presence of errors, the data was exported to the Statistical Package for Social Science (SPSSv.24) to be analysed. The quantitative variables have been described with the mean, standard deviation (SD) and coefficient of variation ( $C V=S D /$ mean*100) and $^{*}$ the qualitative variables with absolute frequency and percentage. The normal distribution of the variables was verified using the Shapiro-Wilk test and the equality of variances using the Levene test. The comparison of mean of independent intergroup variables (males and females) was performed using student t-test, the comparison of the mean of related variables was made with paired $t$-test. The relationship between variables was studied using the Pearson Test. A minimum level of significance of $\mathrm{p}<0.05$ was established.

Height, total body mass, percentage of fat mass, percentage of musculoskeletal mass, BMI, RFM, medial calf and anterior thigh skinfolds, leg and thigh perimeters were used as anthropometric independent variables. The independent ergospirometric variables were the resting heart rate (HR), maximum $\mathrm{HR}_{2} \mathrm{VO}_{2}$ max, maximum speed and maximum respiratory quotient (RER). As dependent variables, for the two muscles: $\mathrm{SmO}_{2}$ at rest, $\mathrm{SmO}_{2}$ at the time of maximum exercise and the difference between them (Dif $\mathrm{SmO}_{2}$ ).

\section{Ethics}

The study was carried out in accordance with the Declaration of Helsinki and was approved by the Research Ethics Commission of the university ID: 2360/2019. The aims and risks of the study were understood before the beginning of the study by all participants, who signed informed consent.

\section{RESULTS}

Table 1 shows the descriptive values of each anthropometric variable.

The $\mathrm{SmO}_{2}$ of both muscles at rest is higher in males than in females. At maximum effort the $\mathrm{SmO}_{2}$ of the quadriceps is similar in both groups. The highest $\mathrm{SmO}_{2}$ losses during exercise occur in the female's gastrocnemius (38.22\%). In the quadriceps, the $\mathrm{SmO}_{2}$ decreases more in the male than in the females and in the gastrocnemius, the opposite happens, noticing a significant variability in both groups. (Table 2)

When comparing the mean $\mathrm{SmO}_{2}$ values between quadriceps and gastrocnemius, it is observed that at rest, before the exercise, in the global population there were no significant differences $(t(19)=0.18, p=0.986)$ and at the time of effort maximum either $(t(19)=0.868, p=0.396)$. There were no differences in males, at rest $(t(9)=-0.95, p=0.394)$ or in maximum exercise $t(9)=-0.984, p=0.351)$. In females, there are no differences in rest $(t(9)=0.946, p=0.369)$ but they are seen in the maximum exercise $(t(9)=2.617, p=0.028)$. In them the differences between the losses in the $\mathrm{SmO}_{2}$ of both muscles in the maximum effort are also significant $(t(9)=-3.063, p=0.014)$.

The correlations between the $\mathrm{SmO}_{2}$ resting values and the anthropometric variables are shown, in Table 3. The $\mathrm{SmO}_{2}$ of both muscles is positively related to height, body mass, percentage of mass muscle and waist contour, and negatively with the percentage of mass fat, RFM

Table 1. Comparison of anthropometric values between males and females.

\begin{tabular}{c|c|c|c|c|c|c|c|c}
\hline & \multicolumn{3}{|c|}{ Males $(\mathbf{n}=10)$} & \multicolumn{3}{c|}{ Females (n=10) } & \multicolumn{2}{c}{ Differences } \\
\hline & Mean & SD & CV \% & Mean & SD & CV \% & $\begin{array}{c}\text { T } \\
\text { Student }\end{array}$ & p-value \\
\hline Age (years) & 21.50 & 0.71 & 3.29 & 21.10 & 0.74 & 3.50 & 1.238 & 0.232 \\
\hline Height (cm) & 174.45 & 5.83 & 3.34 & 158.90 & 9.12 & 5.74 & 4.544 & $0.000^{*}$ \\
\hline Weight (Kg) & 67.41 & 8.17 & 12.11 & 58.65 & 7.05 & 12.02 & 2.568 & $0.019^{*}$ \\
\hline \% Fat body & 16.55 & 3.60 & 21.73 & 30.19 & 6.12 & 20.28 & -6.074 & $0.000^{*}$ \\
\hline \% Muscle mass & 47.14 & 1.84 & 3.90 & 38.34 & 3.46 & 9.03 & 7.103 & $0.000^{*}$ \\
\hline Waist (cm) & 76.50 & 4.40 & 5.76 & 69.05 & 5.46 & 7.91 & 3.359 & $0.003^{*}$ \\
\hline BMI (Kg/m $\left.)^{2}\right)$ & 22.10 & 2.02 & 9.12 & 23.43 & 3.90 & 16.64 & -0.957 & 0.351 \\
\hline RFM (\%) & 18.29 & 2.41 & 13.15 & 29.79 & 3.62 & 12.17 & -8.362 & $0.000^{*}$ \\
\hline Calf skinfold (mm) & 8.06 & 3.15 & 39.04 & 17.50 & 5.38 & 30.75 & -4.788 & $0.000^{*}$ \\
\hline Thigh skinfold (mm) & 19.74 & 6.04 & 30.61 & 33.46 & 6.15 & 18.39 & -5.030 & $0.000^{*}$ \\
\hline Calf perimeter (cm) & 36.60 & 2.46 & 6.72 & 34.90 & 1.60 & 4.57 & 1.834 & 0.083 \\
\hline Thigh perimeter (cm) & 48.48 & 3.46 & 7.15 & 48.55 & 3.84 & 7.91 & -0.043 & 0.966 \\
\hline
\end{tabular}

SD: Standard Deviations, CV: Coefficient of Variation, BMI: Body Mass Index, RFM: Relative Fat Mass.

Table 2. Comparison, between sexes, of the ergometric values and $\mathrm{SmO}_{2}$.

\begin{tabular}{|c|c|c|c|c|c|c|c|c|c|}
\hline & & \multicolumn{3}{|c|}{ Males $(n=10)$} & \multicolumn{3}{|c|}{ Females $(n=10)$} & \multicolumn{2}{|c|}{ Differences } \\
\hline & & Mean & SD & CV \% & Mean & SD & CV \% & $\begin{array}{c}\mathrm{T} \\
\text { Student } \\
\end{array}$ & p-value \\
\hline \multirow{3}{*}{ Rest } & FC (lat/min) & 90.70 & 19.31 & 21.29 & 99.80 & 12.63 & 12.66 & -1.247 & 0.228 \\
\hline & Q $\mathrm{SmO}_{2}(\%)$ & 62.70 & 10.03 & 16.00 & 54.50 & 7.93 & 14.56 & 2.027 & 0.058 \\
\hline & $\mathrm{GSmO}_{2}(\%)$ & 66.30 & 4.97 & 7.49 & 5080 & 16.84 & 33.15 & 2.792 & $0.012^{*}$ \\
\hline \multirow{5}{*}{$\begin{array}{l}\text { Maximum } \\
\text { Effort }\end{array}$} & HR (lat/min) & 19.89 & 6.58 & 192.89 & 179.60 & 26.15 & 14.56 & 1.479 & 0.157 \\
\hline & $\begin{array}{l}\mathrm{VO}_{2}(\mathrm{ml} / \\
\mathrm{Kg} / \mathrm{min})\end{array}$ & 41.50 & 6.00 & 41.50 & 40.40 & 5.87 & 14.54 & 0.414 & 0.684 \\
\hline & $\begin{array}{l}\text { Velocity } \\
(\mathrm{Km} / \mathrm{h})\end{array}$ & 13.23 & 2.05 & 13.23 & 13.34 & 1.87 & 14.02 & -0.125 & 0.902 \\
\hline & $\mathrm{Q} \mathrm{SmO}_{2}(\%)$ & 47.70 & 9.53 & 47.70 & 44.90 & 8.65 & 19.26 & 0.688 & 0.500 \\
\hline & $\mathrm{GSmO}_{2}(\%)$ & 53.40 & 11.98 & 53.40 & 31.70 & 16.29 & 51.39 & 3.393 & $0.003^{* *}$ \\
\hline \multirow{2}{*}{$\begin{array}{l}\text { Decrease in } \\
\text { saturation }\end{array}$} & $\begin{array}{c}\text { Q Dif. } \\
\mathrm{SmO}_{2}(\%)\end{array}$ & 23.40 & 12.66 & 54.08 & 17.60 & 10.01 & 56.87 & 1.137 & 0.270 \\
\hline & $\begin{array}{c}\text { G Dif. } \\
\mathrm{SmO}_{2}(\%)\end{array}$ & 19.73 & 16.08 & 81.53 & 38.22 & 19.27 & 50.42 & -2.330 & $0.032^{*}$ \\
\hline
\end{tabular}

$\mathrm{HR}=$ Heart Rate, $\mathrm{Q}=\mathrm{Quadriceps}, \mathrm{G}=$ Gastrocnemius, Dif= Difference between rest and maximum exercise. 
and skinfolds. The negative relationship of fat percentage with oxygen saturation is more evident in females.

The $\mathrm{SmO}_{2}$ at the moment of maximum effort show the following correlations with the anthropometric and ergometric values. (Table 4) It is observed that the variables that quantify the maximum effort are not related to the $\mathrm{SmO}_{2}$ values except the HR max with the $\mathrm{SmO}_{2}$ of the gastrocnemius in the males.

When correlating the decrease in $\mathrm{SmO}_{2}$ of the quadriceps between the initial values and those obtained at the moment of maximum effort, it is observed that in the global population it is positive with weight and waist circumference. (Table 5) In males, there is also a positive correlation with the percentage of fat and a negative correlation with the percentage of muscle mass. In females there is a positive correlation with weight and relative fat mass and negative with the percentage of muscle mass.

The decrease in the $\mathrm{SmO}_{2}$ of the gastrocnemius, in the global population, only has a positive correlation with the percentage of fat and the RFM. In the male group, it only exists with the height. Females show no correlation. It is noteworthy that there are no correlations between the decrease in saturation of both muscles with the ergometric variables.

\section{DISCUSSION}

We have analysed $\mathrm{SmO}_{2}$, using Humon $\mathrm{Hex}^{\circledast}$, in two muscle groups: quadriceps and gastrocnemius and in two different situations: at rest and when $\mathrm{VO}_{2}$ max was achieved in a stress test carried out on a continuous mat. We observe that at rest, males have significantly higher $\mathrm{SmO}_{2}$ than females in both muscles, but in the stress test males have significantly higher $\mathrm{SmO}_{2}$ than females only in the gastrocnemius.

The relationship of the $\mathrm{SmO}_{2}$ values with the anthropometric values shows a tendency to a negative relationship with the variables related to the presence of fat, and a positive relationship with the muscle variables.

We have observed that, at rest and in both sexes, the $\mathrm{SmO}_{2}$ values are similar when comparing the two muscle groups, whereas after exercise the muscle group that loses the most saturation in males is the quadriceps, while in females it is in gastrocnemius where a greater decreased

Table 3. Correlations between $\mathrm{SmO}_{2}$ of each muscle at rest and anthropometric variables.

\begin{tabular}{|c|c|c|c|c|c|c|c|}
\hline & & \multicolumn{3}{|c|}{$\mathrm{SmO}_{2}$ Quadriceps } & \multicolumn{3}{|c|}{$\mathrm{SmO}_{2}$ Gastrocnemius } \\
\hline & & Everyone & Males & Females & Everyone & Males & Females \\
\hline \multirow{2}{*}{ Height (cm) } & r Pearson & 0.549 & 0.517 & 0.308 & 0.512 & -0.291 & 0.294 \\
\hline & p-value & $0.012^{*}$ & 0.126 & 0.387 & $0.021^{*}$ & 0.415 & 0.410 \\
\hline \multirow{2}{*}{ Weight (Kg) } & r Pearson & 0.581 & 0.702 & 0.116 & 0.166 & -0.275 & -0.171 \\
\hline & $p$-value & $0.007^{* *}$ & $0.024^{*}$ & 0.751 & 0.484 & 0.442 & 0.637 \\
\hline \multirow{2}{*}{ \% Fat body } & r Pearson & -0.391 & 0.322 & -0.376 & -0.665 & -0.160 & -0.513 \\
\hline & $p$-value & 0.088 & 0.365 & 0.284 & $0.001^{* *}$ & 0.660 & 0.129 \\
\hline \multirow{2}{*}{$\begin{array}{c}\% \text { Muscle } \\
\text { mass }\end{array}$} & r Pearson & 0.445 & -0.218 & 0.442 & 0.671 & 0.137 & 0.528 \\
\hline & $p$-value & $0.049^{*}$ & 0.544 & 0.201 & $0.001^{* *}$ & 0.706 & 0.116 \\
\hline \multirow{2}{*}{ Waist (cm) } & r Pearson & 0.480 & 0.656 & -0.047 & 0.190 & -0.013 & -0.306 \\
\hline & p-value & $0.032^{*}$ & $0.039^{*}$ & 0.898 & 0.422 & 0.972 & 0.389 \\
\hline \multirow{2}{*}{$\mathrm{BMI}(\mathrm{Kg} / \mathrm{m} 2)$} & r Pearson & 0.018 & 0.565 & -0.136 & -0.332 & -0.154 & -0.280 \\
\hline & $p$-value & 0.939 & 0.089 & 0.708 & 0.153 & 0.672 & 0.433 \\
\hline \multirow{2}{*}{ RFM (\%) } & r Pearson & -0.367 & 0.400 & -0.251 & -0.634 & 0.133 & -0.502 \\
\hline & $p$-value & 0.112 & 0.252 & 0.485 & $0.003^{* *}$ & 0.715 & 0.139 \\
\hline \multirow{2}{*}{$\begin{array}{c}\text { Thigh skinfold } \\
(\mathrm{mm})\end{array}$} & r Pearson & -0.475 & -0.071 & -0.475 & -0.587 & 0.024 & -0.459 \\
\hline & $p$-value & $0.034^{*}$ & 0.845 & 0.165 & $0.007^{* *}$ & 0.948 & 0.182 \\
\hline \multirow{2}{*}{$\begin{array}{l}\text { Leg skinfold } \\
(\mathrm{mm})\end{array}$} & r Pearson & -0.368 & 0.053 & -0.182 & -0.459 & -0.183 & -0.072 \\
\hline & $p$-value & 0.110 & 0.885 & 0.615 & $0.042^{*}$ & 0.612 & 0.844 \\
\hline \multirow{2}{*}{$\begin{array}{c}\text { Thigh } \\
\text { perimeter }(\mathrm{cm}) \\
\end{array}$} & r Pearson & 0.275 & 0.534 & 0.063 & -0.148 & 0.059 & -0.255 \\
\hline & $p$-value & 0.241 & 0.112 & 0.863 & 0.534 & 0.871 & 0.477 \\
\hline \multirow{2}{*}{$\begin{array}{l}\text { Leg perimeter } \\
(\mathrm{cm})\end{array}$} & r Pearson & 0.633 & 0.636 & 0.413 & 0.212 & -0.317 & 0.129 \\
\hline & $p$-value & $0.003^{* *}$ & $0.048^{*}$ & 0.236 & 0.369 & 0.373 & 0.721 \\
\hline
\end{tabular}

Table 4. Correlations between $\mathrm{SmO}_{2}$ of each muscle in maximum effort and the anthropometric and ergometric variables.

\begin{tabular}{|c|c|c|c|c|c|c|c|}
\hline & & \multicolumn{3}{|c|}{ SmO2 QUADRICEPS } & \multicolumn{3}{|c|}{ SmO2 GASTROCNEMIUS } \\
\hline & & Everyone & Males & Females & Everyone & Males & Females \\
\hline \multirow{2}{*}{ Height (cm) } & Pearson & 0.227 & -0.039 & 0.316 & 0.508 & -0.660 & 0.453 \\
\hline & p-value & 0.336 & 0.914 & 0.373 & $0.022^{*}$ & $0.038^{*}$ & 0.189 \\
\hline \multirow{2}{*}{ Weight (Kg) } & r Pearson & 0.035 & 0.132 & -0.297 & 0.088 & -0.470 & -0.270 \\
\hline & p-value & 0.882 & 0.715 & 0.405 & 0.713 & 0.171 & 0.450 \\
\hline \multirow{2}{*}{ Fat Mass (\%) } & Pearson & -0.424 & -0.290 & -0.706 & -0.657 & -0.067 & -0.436 \\
\hline & p-value & 0.063 & 0.417 & $0.023^{*}$ & $0.002^{* *}$ & 0.853 & 0.207 \\
\hline \multirow{2}{*}{$\begin{array}{c}\text { Muscle } \\
\text { Mass (\%) }\end{array}$} & r Pearson & 0.427 & 0.357 & 0.756 & 0.648 & -0.039 & 0.408 \\
\hline & p-value & 0.060 & 0.311 & $0.011^{*}$ & $0.002^{* *}$ & 0.916 & 0.241 \\
\hline \multirow{2}{*}{ Waist (cm) } & r Pearson & 0.018 & 0.212 & -0.388 & 0.291 & -0.025 & -0.237 \\
\hline & p-value & 0.939 & 0.557 & 0.268 & 0.213 & 0.945 & 0.510 \\
\hline \multirow{2}{*}{$\mathrm{BMI}(\mathrm{Kg} / \mathrm{m} 2)$} & r Pearson & -0.224 & 0.210 & -0.448 & -0.432 & -0.146 & -0.485 \\
\hline & p-value & 0.343 & 0.560 & 0.194 & 0.057 & 0.687 & 0.155 \\
\hline \multirow{2}{*}{ RFM (\%) } & r Pearson & -0.240 & 0.262 & -0.582 & -0.652 & 0.386 & -0.587 \\
\hline & $p$-value & 0.307 & 0.464 & 0.077 & $0.002^{* *}$ & 0.270 & 0.074 \\
\hline \multirow{2}{*}{$\begin{array}{c}\text { Thigh skinfold } \\
(\mathrm{mm})\end{array}$} & r Pearson & -0.295 & 0.225 & -0.808 & -0.605 & -0.013 & -0.431 \\
\hline & p-value & 0.207 & 0.533 & $0.005^{*}$ & $0.005^{*}$ & 0.972 & 0.213 \\
\hline \multirow{2}{*}{$\begin{array}{l}\text { Calf skin } \\
\text { fold (mm) }\end{array}$} & r Pearson & -0.395 & -0.187 & -0.605 & -0.499 & -0.149 & -0.022 \\
\hline & p-value & 0.085 & 0.605 & 0.064 & $0.025^{*}$ & 0.682 & 0.952 \\
\hline \multirow{2}{*}{$\begin{array}{c}\text { Thigh } \\
\text { perimeter }(\mathrm{cm})\end{array}$} & r Pearson & -0.071 & 0.145 & -0.286 & -0.228 & 0.000 & -0.475 \\
\hline & $p$-value & 0.765 & 0.690 & 0.423 & 0.334 & 0.999 & 0.165 \\
\hline \multirow{2}{*}{$\begin{array}{c}\text { Calf perimeter } \\
(\mathrm{cm})\end{array}$} & r Pearson & 0.246 & 0.210 & 0.193 & 0.025 & -0.447 & -0.204 \\
\hline & p-value & 0.297 & 0.560 & 0.594 & 0.508 & 0.196 & 0.571 \\
\hline \multirow{2}{*}{$\begin{array}{c}\mathrm{VO}_{2} \max \\
(\mathrm{ml} / \mathrm{Kg} / \mathrm{min})\end{array}$} & r Pearson & -0.173 & -0.158 & -0.231 & -0.009 & 0.389 & -0.452 \\
\hline & p-value & 0.465 & 0,663 & 0.521 & 0.970 & 0.266 & 0.190 \\
\hline \multirow{2}{*}{$\begin{array}{l}\text { HR max } \\
\text { (lat/min) }\end{array}$} & r Pearson & 0.331 & 0,199 & 0.403 & 0.320 & -0.573 & 0.275 \\
\hline & $p$-value & 0.167 & 0,608 & 0.248 & 0.182 & 0.107 & 0.442 \\
\hline \multirow{2}{*}{$V \max (\mathrm{Km} / \mathrm{h})$} & r Pearson & -0.337 & $-0,322$ & -0.354 & -0.123 & 0.342 & -0.525 \\
\hline & p-value & 0.146 & 0,364 & 0.315 & 0.604 & 0.333 & 0.120 \\
\hline \multirow{2}{*}{ RER } & r Pearson & -0.575 & $-0,528$ & -0.790 & 0.234 & 0.411 & -0.115 \\
\hline & p-value & $0.010^{*}$ & 0,144 & 0.007 & 0.336 & 0.272 & 0.751 \\
\hline
\end{tabular}

BMI = Body Mass Index, RFM=Relative Fat Mass, VO2 max= Maximum oxygen consumption, FCmax = Maximum heart rate, $V=$ Velocity, $R E R=$ respiratory quotient, ${ }^{*} p<0,05 .{ }^{* *} p<0,01$.

of saturation is produced. This could be due to the different muscle mass of these groups in each sex ${ }^{10}$ or to mechanical differences in the race. ${ }^{16}$ In the quadriceps a greater correlation is observed between the anthropometric variables and the $\mathrm{SmO}_{2}$ at rest than after exercise, while in the gastrocnemius these correlations are also maintained in the maximum exercise, which could be related to fatigue or tolerance to maximum effort.

The exercise has been performed running on a continuous treadmill, so the two muscles work together. ${ }^{9}$ The slope has remained constant, which has not caused a special overload on the gastrocnemius muscles as it occurs in the ramp race. ${ }^{23}$ The results of this work can be used to understand better the participation of each muscle group in running mechanics and in the appearance of fatigue. Thus, we have observed that in females a greater loss of saturation appears, significantly, in gastrocnemius than in quadriceps. Like Bastida-Castillo et al.. ${ }^{24}$ we believe that the point of the placement of the device should be specific to the type of exercise that is going to be performed, as it allows the different oxygenation changes produced in muscle tissue to be detected. 
Table 5. Correlations between the decreases in oxygen saturation in each muscle with anthropometric and ergometric variables.

\begin{tabular}{|c|c|c|c|c|c|c|c|}
\hline & & \multicolumn{3}{|c|}{$\begin{array}{l}\text { Decrease } \mathrm{SmO}_{2} \\
\text { QUADRICEPS }\end{array}$} & \multicolumn{3}{|c|}{$\begin{array}{c}\text { Decrease } \mathrm{SmO}_{2} \\
\text { GASTROCNEMIUS }\end{array}$} \\
\hline & & \begin{tabular}{|l|} 
Everyone \\
\end{tabular} & Males & Females & Everyone & Males & Females \\
\hline \multirow{2}{*}{ Height $(\mathrm{cm})$} & r Pearson & 0.296 & 0.538 & -0.125 & -0.357 & \begin{tabular}{|l|}
0.649 \\
\end{tabular} & -0.360 \\
\hline & $p$-value & 0.205 & 0.109 & 0.730 & 0.122 & $0.042^{*}$ & 0.306 \\
\hline \multirow{2}{*}{ Weight(Kg) } & r Pearson & 0.596 & 0.495 & 0.655 & -0.001 & 0.426 & 0.250 \\
\hline & $p$-value & $0.006^{* *}$ & 0.146 & $0.040^{*}$ & 0.998 & 0.220 & 0.487 \\
\hline \multirow{2}{*}{$\%$ Fat mass } & r Pearson & 0.137 & \begin{tabular}{|l|}
0.644 \\
\end{tabular} & 0.701 & 0.426 & 0.007 & 0.091 \\
\hline & $p$-value & 0.565 & $0.044^{*}$ & $0.024^{*}$ & 0.061 & 0.985 & 0.804 \\
\hline \multirow{2}{*}{$\begin{array}{l}\% \text { Muscle } \\
\text { mass }\end{array}$} & r Pearson & -0.081 & -0.625 & -0.697 & -0.411 & 0.106 & -0.041 \\
\hline & $p$-value & 0.735 & $0.043^{*}$ & $0.025^{*}$ & 0.071 & \begin{tabular}{|l|}
0.771 \\
\end{tabular} & 0.911 \\
\hline \multirow{2}{*}{ Waist (cm) } & r Pearson & 0,506 & 0.334 & 0.605 & -0.294 & 0.009 & 0.005 \\
\hline & $p$-value & $0.023^{*}$ & 0.345 & 0.064 & 0.208 & 0.981 & 0.989 \\
\hline \multirow{2}{*}{ BMI $(\mathrm{Kg} / \mathrm{m} 2)$} & r Pearson & 0.334 & \begin{tabular}{|l|}
0.268 \\
\end{tabular} & 0.578 & 0.388 & 0.096 & 0.442 \\
\hline & $p$-value & 0.150 & 0.455 & 0.080 & 0.091 & 0.793 & 0.201 \\
\hline \multirow{2}{*}{ RFM (\%) } & r Pearson & -0.078 & 0.027 & 0.656 & 0.454 & -0.413 & 0.324 \\
\hline & $p$-value & 0.745 & \begin{tabular}{|l|}
0.941 \\
\end{tabular} & $0.040^{*}$ & $0.045^{*}$ & 0.236 & 0.360 \\
\hline \multirow{2}{*}{$\begin{array}{l}\text { Thigh skinfold } \\
(\mathrm{mm})\end{array}$} & r Pearson & -0.100 & -0.279 & 0.699 & 0.433 & 0.012 & 0.201 \\
\hline & $p$-value & 0.673 & 0.436 & $0.024^{*}$ & 0.056 & \begin{tabular}{|l|}
0.974 \\
\end{tabular} & 0.578 \\
\hline \multirow{2}{*}{$\begin{array}{c}\text { Calf skinfold } \\
(\mathrm{mm})\end{array}$} & r Pearson & 0.155 & \begin{tabular}{|l|}
0.318 \\
\end{tabular} & 0.783 & 0.346 & \begin{tabular}{|l|}
0.077 \\
\end{tabular} & -0.074 \\
\hline & $p$-value & 0.513 & \begin{tabular}{|l|}
0.371 \\
\end{tabular} & $0.007^{*}$ & 0.135 & 0.832 & 0.839 \\
\hline \multirow{2}{*}{\begin{tabular}{c|} 
Thigh \\
perimeter $(\mathrm{cm})$
\end{tabular}} & \begin{tabular}{|l|} 
r Pearson \\
\end{tabular} & 0.399 & \begin{tabular}{|l|}
0.298 \\
\end{tabular} & 0.564 & 0.218 & \begin{tabular}{|l|}
0.001 \\
\end{tabular} & 0.425 \\
\hline & $p$-value & 0.081 & \begin{tabular}{|l|l|}
0.404 \\
\end{tabular} & 0.090 & 0.356 & \begin{tabular}{|l|}
0.997 \\
\end{tabular} & 0.221 \\
\hline \multirow{2}{*}{$\begin{array}{c}\text { Calf perimeter } \\
(\mathrm{cm})\end{array}$} & r Pearson & 0.383 & 0.352 & 0.252 & 0.119 & 0.385 & 0.428 \\
\hline & $p$-value & 0.095 & 0.319 & 0.482 & 0.616 & 0.273 & 0.217 \\
\hline \multirow{2}{*}{$\begin{array}{c}\mathrm{VO}_{2} \max \\
(\mathrm{ml} / \mathrm{Kg} / \mathrm{min})\end{array}$} & r Pearson & -0.213 & \begin{tabular}{|l|}
-0.224 \\
\end{tabular} & -0.281 & -0.030 & -0.377 & 0.359 \\
\hline & $p$-value & 0.368 & 0.534 & 0.432 & 0.901 & 0.282 & 0.309 \\
\hline \multirow{2}{*}{$\begin{array}{l}\text { HR max } \\
\text { (lat/min) }\end{array}$} & r Pearson & -0.248 & -0.140 & -0.548 & -0.197 & 0.465 & -0.143 \\
\hline & $p$-value & 0.306 & \begin{tabular}{|l|}
0.720 \\
\end{tabular} & 0.101 & 0.418 & 0.207 & 0.694 \\
\hline \multirow{2}{*}{$V \max (\mathrm{Km} / \mathrm{h})$} & r Pearson & -0.148 & -0.103 & -0.205 & 0.047 & -0.343 & 0.387 \\
\hline & $p$-value & 0.533 & \begin{tabular}{|l|}
0.777 \\
\end{tabular} & 0.570 & 0.843 & \begin{tabular}{|l|}
0.332 \\
\end{tabular} & 0.269 \\
\hline \multirow{2}{*}{ RER } & r Pearson & 0.401 & 0.375 & 0.368 & -0.434 & -0.464 & -0.280 \\
\hline & p-value & 0.089 & 0.320 & 0.296 & 0.063 & 0.208 & 0.433 \\
\hline
\end{tabular}

BMI = Body Mass Index, RFM= Relative Fat Mass, VO2 max= Maximum oxygen consumption, HR max = Maximum Heart Rate, V max= Maximum Velocity, RER= Respiratory Quotient, ${ }^{*} p<0,05$. ${ }^{* *} p<0,01$.

The differences in oxygenation between males and females have been significant in gastrocnemius and could be related to the different muscle mass of each group. ${ }^{17}$ The higher the percentage of mass muscle, the higher the percentage of oxygenation and inversely with the adipose panniculus, the higher the fat, the lower the saturation value.

The design of these devices, in which the distance between the emitter and the light detector is almost equal to the depth of penetration into the muscle makes the subcutaneous adipose tissue to influence the NIRS signal intensity to a great extent. ${ }^{5}$ However, correction algorithms included in some of the NIRS devices have been develop. ${ }^{25}$

Thigh and calf skinfolds were negatively correlated with $\mathrm{SmO}_{2}$ values, similar to what was shown by Van der Zwaard et al. ${ }^{15}$ while the perimeters of the thigh and the leg do not show significant relationships with the quadriceps and gastrocnemius muscle saturation, possibly due to not discriminating between fat and muscle mass. If we had had a more heterogeneous population in body composition, more differences could have been found, between the subjects, related to the percentages of fat and muscle and to local anthropometric measurements (folds and perimeter). We have related muscle activity through running exercise in a continuous treadmill, but other authors such as Yoshimatsu et al. ${ }^{26}$ have done it with strength exercises, also concluding that NIRS technology can be used to see the relationships between muscle mass, strength and the adipose panicle.

The BMI does not maintain a relations hip with saturation, possibly due to not differentiating between fat and muscle, so this is another factor to take into account to avoid considering it as a good predictor, neither of obesity nor of physical condition. ${ }^{20}$

The use of the NIRS allows to develop an optimal work plan, in training as well as in rehabilitation, in order to establish personalized exercise intensities. With this knowledge, the athlete can know to what extent they must strive without exceeding their limits and thus optimize their performance; associating this with high- level sport, Belloti et al. ${ }^{27}$ related the changes in $\mathrm{SmO}_{2}$ with lactate measurements to see its correlation and help plan training.

As in previous studies, it was verified that heart rate and $\mathrm{VO}_{2}$ are physiological parameters with a clear relationship with $\mathrm{SmO}_{2}$. When the muscle is in the aerobic phase, the $\mathrm{HR}$ increases, the $\mathrm{SmO}_{2}$ increases or is maintained, and it decreases when the muscle tissue is introduced in the anaerobic phase. ${ }^{28}$

One limitation of our results is that they can only be applied to our population. That is, healthy young people who exercise regularly but not competitively.

The NIRS device is a relevant meter of the different physiological parameters during the practice of intense physical exercise. ${ }^{29}$ It allows us to work in a more dynamic way with athletes in a larger area without having to be in a physical medicine laboratory and thus be able to carry out the training that the athlete usually practices in his day by day.

\section{CONCLUSION}

We can conclude that the $\mathrm{SmO}_{2}$ assessment of recreational athletes is influenced by the location of the device and the fat mass of the subject, with greater differences between males and females in gastrocnemius. At the moment of maximum effort, the $\mathrm{SmO}_{2}$ of the gastrocnemius maintains an inverse relationship with the fat content of the person in general and with the lower limb in particular.

\section{ACKNOWLEDGEMENTS}

We would like to thank all the participants who have contributed to this research.

All authors declare no potential conflict of interest related to this article

AUTHORS' CONTRIBUTIONS: Each author made significant individual contributions to this manuscript. MJPR: elaboration of the research project, writing, data collection, statistical analysis and revision of the written article; MJR: data collection and revision of the article;VFR: writing, revision, and intellectual concept; IMGM: elaboration of the research project, writing, data collection, statistical analysis and revision of the written article. All authors revised and approved the final version of the manuscript.

\section{REFERENCES}

1. Özyener F. Evaluation of intra-Musclar oxygenation during exercise in humans. J Sports Sci Med. 2002;1(1):15-9.

2. Inglis EC, lannetta $D$, Murias JM. Evaluating the NIRS-derived microvascular $\mathrm{O}_{2}$ extraction "reserve" in groups varying in sex and training status using leg blood flow occlusions. PLoS One. 2019;14(7):1-33.

3. 3. Ryan TE, Brophy P, Lin CT, Hickner RC, Neufer PD. Assessment of in vivo skeletal muscle mitochondrial respiratory capacity in humans by near-infrared spectroscopy: a comparison with in situ measurements. J Physiol. 2014;592(15):3231-41.
4. Willingham TB, McCully KK. In vivo assessment of mitochondrial dysfunction in clinical populations using near-Infrared spectroscopy. Front Physiol. 2017;8(1):1-11.

5. Ferrari M, Mottola L, Quaresima V. Principles, techniques and limitations of near infrared spectroscopy. J Appl Physiol. 2004;29(4):463-87.

6. Hamaoka T,McCully KK, Quaresima V, Yamamoto K, Chance B. Near-infrared spectroscopy/imaging for monitoring muscle oxygenation and oxidative metabolism in healthy and diseased humans. J Biomed Opt. 2007;12(6):1-16.

7. Wilkinson TJ, White A, Nixon DG, Gould DW, Watson EL, Smith A. Characterising skeletal muscle 
haemoglobin saturation during exercise using near-infrared spectroscopy in chronic kidney disease. Clin Exp Nephrol. 2019;23(1):32-42.

8. Dias VW, Thomas C, Passerieux E, Hugon G, Pillard F, Andrade A, et al. Impaired oxygen demand during exercise is related to oxidative stress and muscle function in facioscapulohumeral muscular dystrophy. Phy Med Exp. 2018;1(1):1-14.

9. Williamson S, Sanni AA, McCully KK. The influence of muscle length on gastrocnemius and vastus lateralis muscle oxygen saturation and endurance. J Electromyogr Kinesiol. 2019;49(1):1-5.

10.Jones S, D'Silva A, Bhuva A, Lloyd G, Manisty C, Moon JC, et al. Improved exercise-related skeletal muscle oxygen consumption following uptake of endurance training measured using near-infrared spectroscopy. Front physiol. 2017;8(1):1018.

11.Endo T, Kime R, Watanabe T, Fuse S, Murase N, Kurosawa Y, et al. Reduced optical path length in the vastus lateralis during ramp cycling exercise. Adv Exp Med Biol. 2020;1232(1):239-44.

12. Humon. Humon Hex. Available in: https://humon.es/[Access 4 april 2020].

13.Peng G, Bing-Hong G. Correlation between muscle oxygen and cardiopulmonary of young cyclists at ventilation threshold. Exerc Bioc Rev. 2018;1(3):23-5.

14. Casajús JA, Piedrafita E, Aragonés MT. Criteria for maximal exercise test. Rev Int Med Cienc Act Fis Deporte. 2009;9(35):217-31.

15. Van der Zwaard S, De Ruiter CJ, Noordhof DA, Sterrenburg R, Bloemers FW, De Koning JJ, et al. Maximal oxygen uptake is proportional to muscle fiber oxidative capacity, from chronic heart failure patients to professional cyclists. J Appl Physiol. 2016;121(3):636-45.

16. Gepner Y, Wells A, Gordon JA, Vera AN, Varanoske NA, Coker DH. Differences in muscle oxygenation between young and middle-aged recreationally active men during high-volume resistance exercise. Kinesiology. 2019;51(1):3-11.

17. Kuroiwa M, Fuse S, Amagasa S, Kime R, Endo T, Kurosawa Y, et al. Relationship of total hemoglobin in subcutaneous adipose tissue with whole-body and visceral adiposity in humans. Appl Sci. 2019;9(12):2442.

18. Cournoyer A, Cossette S, Paquet J, Daoust R, Marquis M, Notebaert É, et al. Association between the quantity of subcutaneous fat and the inter-device agreement of 2 tissue Oximeters. J Cardiothorac Vasc Anesth. 2019;33(11):2989-94.

19. Lucero A, Addae G, Lawrence W, Neyway B, Credeur DP, Faulkner J, et al. Reliability of muscle bloodflow and oxygen consumption response from exercise using near-infrared spectroscopy. Exp Physiol. 2018;103(1):90-100.

20. Woolcott OO, Bergman RN. Relative fat mass (RFM) as a new estimator of whole-body fat percentage - A cross-sectional study in American adult individuals. Sci Rep. 2018;8(1):1-11.

21. Howley ET, Bassett DR, Welch HG. Criteria for maximal oxygen uptake: review and commentary. Med Sci Sports Exerc. 1995;27(1):1292-2

22. Fletcher JR, Esau SP, Macintosh BR. Economy of running: beyond the measurement of oxygen uptake. J Appl Physiol. 2009;107(6):1918-22

23. Hindistan IE, Ozdogan EC, Bilgin G, Colak OH, Ozkaya YG. Effects of sprint interval training on sloping surfaces on aerobic and anaerobic power. Biomed Hum Kinet. 2020;12(2):41-50.

24. Bastida-Castillo A, Gómez-Carmona CD, Pino Ortega J. Effects of recovery type in muscular oxygenation during squat exercise. Kronos. 2016;2(15):1-12.

25. Niwayama M, Yamamoto K, Kohata D, Hirai K, Kudo N, Hamaoka T. A 200-channel imaging system of muscle oxygenation using CW near infrared spectroscopy. Trans Inf Syst. 2002;85(1):115-23.

26. Yoshimatsu T, Yoshida D, Shimada H, Komatsu T. Relationship between near-infrared spectroscopy and subcutaneous fat and muscle thickness measured by ultrasonography in Japanese community-dwelling elderly. Geriatr Gerontol Int. 2013;13(2):351-7.

27. Bellotti C, Calabria E, Capelli C, Pogliaghi S. Determination of maximal lactate steady state in healthy adults: can NIRS help. Med Sci Sports Exerc. 2013;45(6):1208-16.

28. Crum EM, O'Connor WJ, Van Loo L, Valckx M, Stannard SR. Validity and reliability of the Moxy oxygen monitor during incremental cycling exercise. J Physiol Sci. 2017;17(8):1037-43.

29. Paredes-Ruiz MJ, Jódar-Reverte M, Ferrer-Lopez V, Martínez-González-Moro I. Quadriceps muscle oxygenation during a maximum stress test in middle-aged athletes. Montenen J Sport Sci Med. 2020;9(2):202-6 